\title{
POTENSI BEBERAPA ASESI KACANG PANJANG (Vigna unguiculata ssp. Sesquipedalis) SEBAGAI PAKAN DI INDONESIA
}

\author{
Nafiatul Umami ${ }^{1}$, Meita Puspa Dewi ${ }^{2}$, Andru$^{1}$, Dian Astuti ${ }^{3}$, Rahmi Tri Sayekti ${ }^{3}$, Taryono ${ }^{3}$ \\ ${ }^{1}$ Fakultas Peternakan, Universitas Gadjah Mada, Yogyakarta \\ ${ }^{2}$ Fakultas Industri Halal, Universitas Nahdlatul Ulama, Yogyakarta \\ ${ }^{3}$ Pusat Inovasi Agroteknologi, Universitas Gadjah Mada, Yogyakarta \\ Corresponding author: nafiatul.umami@ugm.ac.id
}

\begin{abstract}
ABSTRAK
Penelitian ini bertujuan untuk menyeleksi asesi tanaman kacang panjang (Vigna unguiculata ssp. Sesquipedalis) dan menginovasi teknologi pembenihan baru kacang panjang untuk kemandirian pakan ternak. Penelitian dilakukan di rumah kaca Pusat Inovasi Agroteknologi, Universitas Gadjah Mada pada bulan April sampai Oktober 2019. Penelitian menggunakan rancangan acak lengkap pola searah (one way anova) dengan perlakuan 40 asesi kacang panjang milik PIAT UGM. Variabel yang diamati yaitu pertumbuhan tanaman (tinggi dan panjang tanaman), produksi segar, kandungan nutrient (bahan kering (BK), bahan organik (BO), serat kasar (SK) dan lemak kasar (LK)). Hasil penelitian menunjukkan bahwa 5 nomer aksesi terbaik dari 40 asesi berdasarkan produksi segar diantaranya asesi kacang panjang nomer 225, 158, 141, 360 dan 153 dengan produksi segar paling tinggi dengan produksi segar 24,84 ton/ha dengan nomer asesi 225. Nomor asesi 225 memiliki kandungan bahan kering dan lemak kasar tertinggi dengan serat kasar yang rendah. Berdasarkan penelitian dapat disimpulkan bahwa nomor asesi 225 memiliki kandungan nutrient dan produksi yang terbaik.
\end{abstract}

Kata kunci: kacang panjang, kandungan nutrien, pertumbuhan, produksi

\section{PENDAHULUAN}

Produktivitas ternak ruminansia dapat dicapai melalui perbaikan penyediaan hijauan pakan, baik dari segi kualitas maupun kuantitas secara kontinyu. Hijauan pakan merupakan sumber pakan utama bagi ruminansia dikarenakan mengandung zat-zat makanan yang dibutuhkan oleh ternak. Ketersediaan hijauan harus tetap ada sepanjang tahun sehingga untuk memenuhi kebutuhan tersebut maka perlu dilakukan upaya peningkatan produksi. Limbah hasil pertanian yang bernilai nutrien tinggi kurang dimanfaatkan oleh peternak. Salah satu limbah pertanian yang memiliki protein tinggi adalah limbah kacang-kacangan.

Tanaman kacang-kacangan banyak ditanam karena bijinya mengandung kadar protein yang tinggi. Adapun jenis tanaman kacang-kacangan yang banyak dibudidayakan di Indonesia adalah kedelai, kacang tanah, dan kacang hijau, sedangkan kacang panjang masih belum banyak diketahui dan dibudidayakan oleh petani. Haliza et al. (2010), menyatakan kelebihan lain dari kacang panjang berpolong merah yaitu toleran terhadap hama dan penyakit karena memiliki kulit polong yang tebal dan keras sehingga tidak disukai hama. Suryadi (2003), tanaman ini berumur pendek, tahan terhadap kekeringan, tumbuh baik pada dataran medium sampai dataran rendah, dapat ditanam di lahan sawah, tegalan, atau pekarangan pada setiap musim. Valenzuela dan Smith (2002) menyatakan, tanaman kacang panjang mempunyai peran penting dalam menyuburkan tanah. Hal ini dikarenakan tanaman kacang panjang mempunyai bintil-bintil akar yang bisa mengikat nitrogen bebas di udara. Anto (2013) menyatakan bahwa nilai nutrien daun kacang panjang per 100 gram bahan yaitu energy $44 \mathrm{Kal}$, protein 2,7 gram, lemak 0,3 gram, dan karbohidrat 7,8 gram.

Pusat Inovasi Agroteknologi memiliki 40 asesi tanaman kacang panjang. Namun demikian, belum ditemukan tanaman kacang panjang yang memiliki produksi daun tinggi yang cocok untuk pakan ternak. Oleh karena itu dilakukan seleksi tanaman kacang panjang dengan teknik mengamati produksi dan kandungan nutrien dari tiap-tiap asesi tanaman kacang panjang milik PIAT UGM. Penelitian seleksi asesi pada Vigna unguiculata ssp. Sesquipedalis penting untuk dilakukan untuk mengatasi masalah ketersediaan pakan di Indonesia sehingga tercipta kemandirian pakan yang mana nantinya tersedia benih tanaman pakan unggul.

\section{MATERI DAN METODE}

Penelitian dilaksanakan di Pusat Inovasi Agroteknologi, Universitas Gadjah Mada (Kalitirto, Berbah, Sleman, Yogyakarta). Waktu penelitian dilakukan pada bulan April sampai Oktober 2019. 


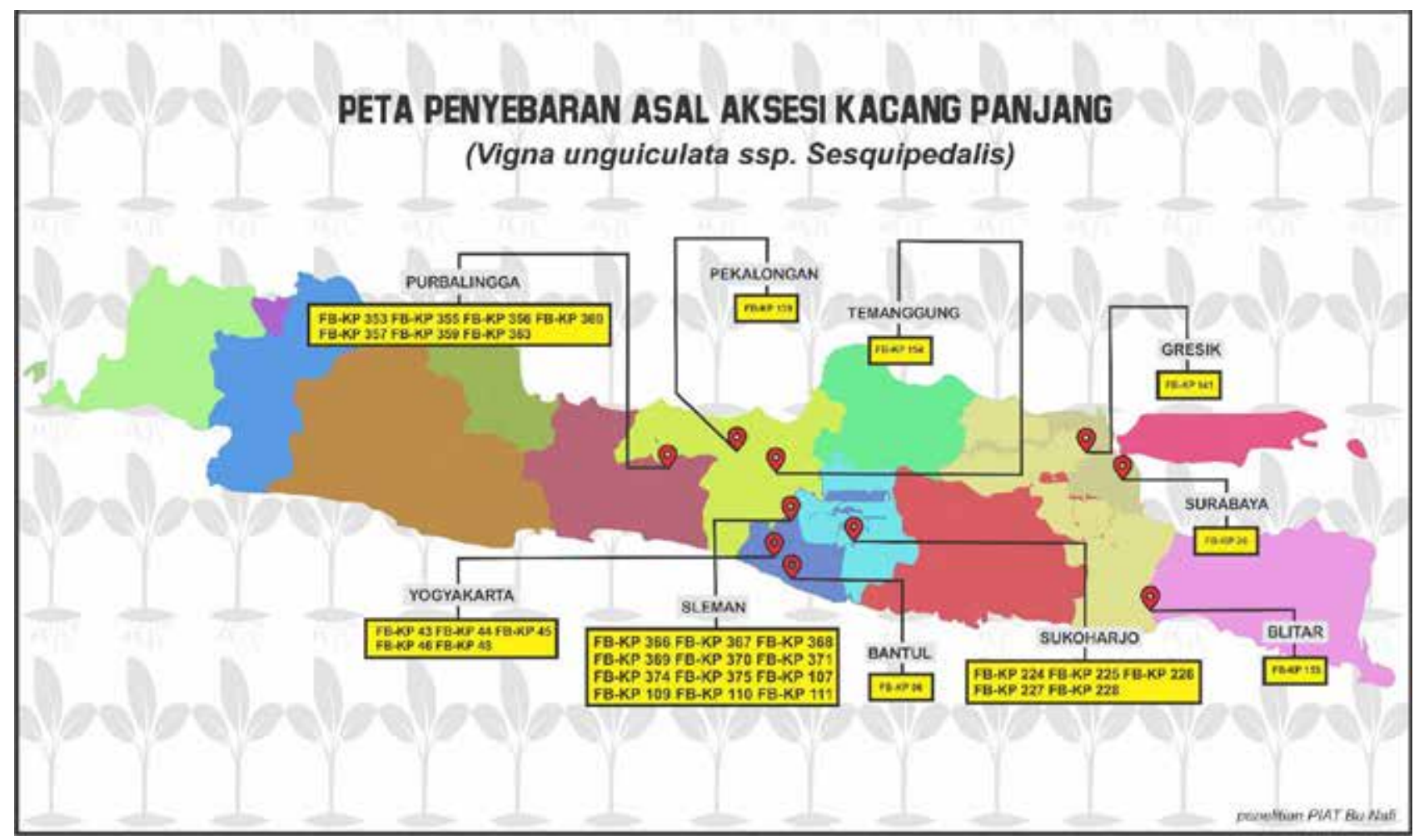

Gambar 1. Peta persebaran asal asesi kacang panjang

Rancangan percobaan yang digunakan dalam penelitian ini adalah rancangan acak lengkap pola searah (one way anova) dengan perlakuan 40 asesi kacang panjang.

Variabel yang diamati meliputi pertumbuhan (tinggi dan panjang tanaman), produksi segar, kandungan nutrient (bahan kering, bahan organik, serat kasar dan lemak kasar (AOAC, 2005)). Data yang diperoleh dianalisis dengan sidik ragam dan apabila perlakuan menunjukkan perbedaan yang nyata $(\mathrm{P}<0,05)$, maka diuji dengan Duncan's Multiple Range Test (DMRT) (Astuti, 1980).

\section{HASIL DAN PEMBAHASAN}

Hasil penelitian menunjukkan perlakuan perbedaan asesi kacang panjang berpengaruh nyata $(\mathrm{P}<0,05)$ terhadap pertumbuhan tanaman kacang panjang (tinggi dan panjang tanaman). Grafik tinggi dan panjang tanaman 40 asesi dapat dilihat pada Gambar 2 dan 3. Peta penyebaran asal asesi kacang panjang asesi milik PIAT UGM dapat dilihat pada Gambar 1.

Hasil uji analisis statistik menunjukkan bahwa tanaman kacang panjang dengan nomor asesi 360 merupakan kacang panjang yang paling tinggi dengan tinggi tanaman $175 \mathrm{~cm}$. Asesi kacang panjang yang terendah yaitu nomor 96 dengan tinggi tanaman 146 $\mathrm{cm}$. Nomor asesi kacang panjang 360 berasal dari daerah Purbalingga, sedangkan nomor 96 berasal dari daerah Bantul.

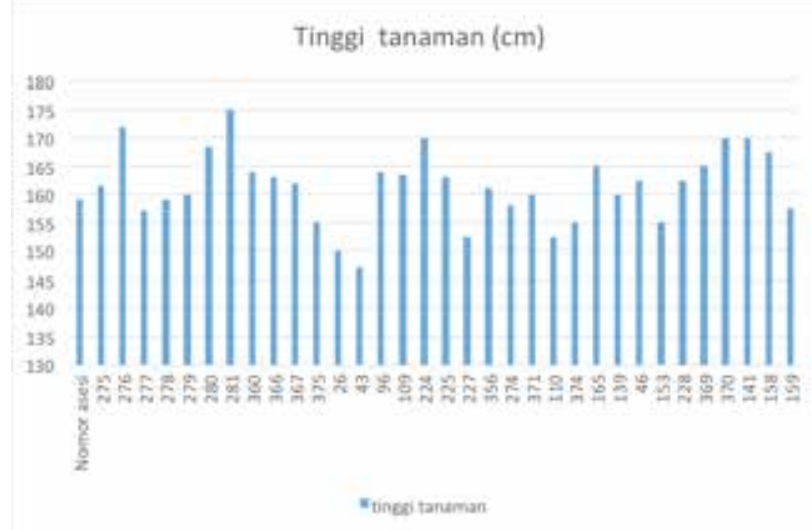

Gambar 2. Tinggi tanaman kacang panjang

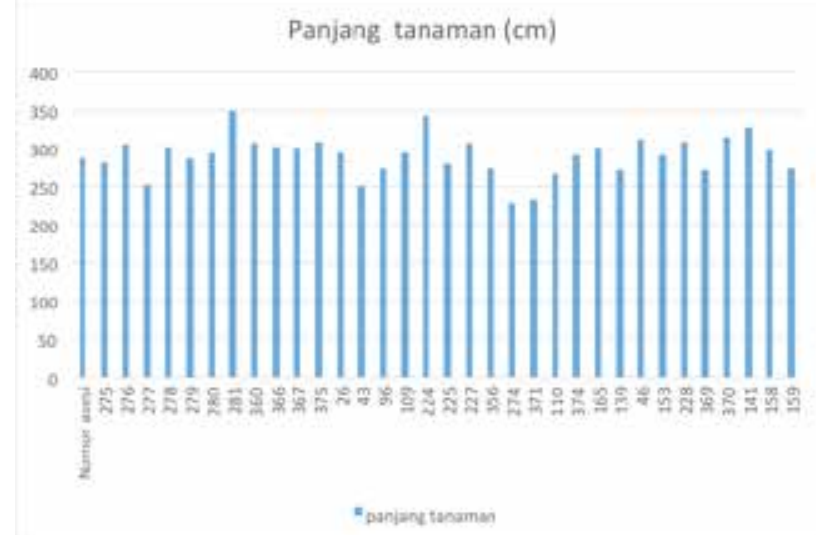

Gambar 3. Panjang tanaman kacang panjang

Berdasarkan hasil uji statistik menunjukkan bahwa perbedaan nomor asesi kacang panjang berpengaruh nyata terhadap produksi segar (ton/ha). Hasil 
produksi segar dapat dilihat pada Gambar 4. Jumlah produksi segar merupakan penentu untuk menyeleksi lima tanaman kacang panjang terbaik dari 40 asesi kacang panjang yang ditanam. Hasil produksi segar menunjukkan hasil yang signifikan terhadap setiap aksesi, tanaman kacang panjang dengan nomer aksesi 360, 356, 158, 141 dan 225 merupakan lima tanaman terbaik dari 40 nomer asesi yang diseleksi dan selanjutnya akan dilanjutkan uji kandungan nutrient.

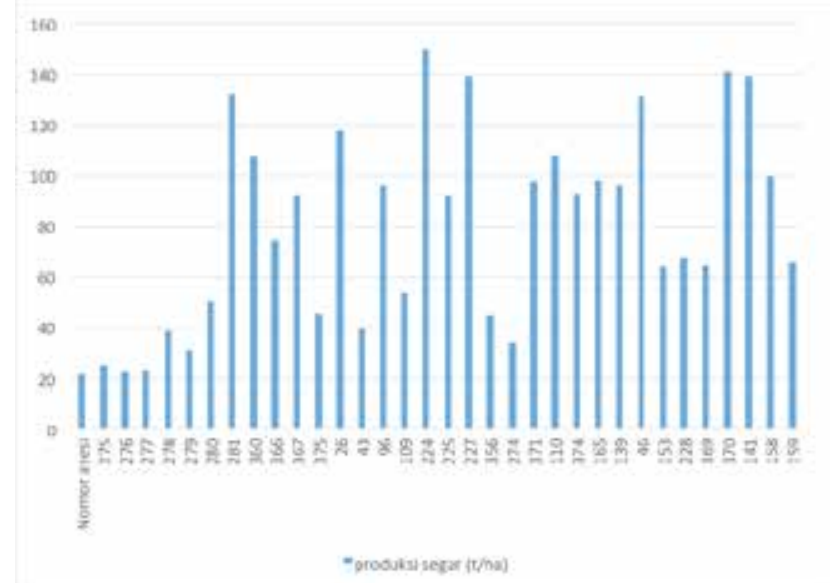

Gambar 4. Produksi segar kacang panjang

Tabel 1. Kandungan nutrient kacang panjang

\begin{tabular}{lcc}
\hline \multicolumn{2}{c}{ Variabel } & Rerata \\
\hline Bahan kering & 141 & $13,01^{\mathrm{a}}$ \\
& 360 & $15,58^{\mathrm{b}}$ \\
& 225 & $15,69^{\mathrm{b}}$ \\
& 158 & $13,59^{\mathrm{a}}$ \\
Bahan organik & 153 & $12,38^{\mathrm{a}}$ \\
& 141 & \\
& 360 & $87,04^{\mathrm{b}}$ \\
& 225 & $88,06^{\mathrm{b}}$ \\
& 158 & $86,71^{\mathrm{a}}$ \\
Lemak kasar & 153 & $85,6^{\mathrm{a}}$ \\
& 141 & $87,61^{\mathrm{b}}$ \\
& 360 & $2,37^{\mathrm{ab}}$ \\
& 225 & $2,52^{\mathrm{ab}}$ \\
& 158 & $3,05^{\mathrm{b}}$ \\
& 153 & $2,96^{\mathrm{b}}$ \\
& & $1,66^{\mathrm{a}}$ \\
& 141 & $15,27^{\mathrm{b}}$ \\
& 360 & $15,38^{\mathrm{b}}$ \\
& 225 & $10,18^{\mathrm{a}}$ \\
& 158 & $14,75^{\mathrm{b}}$ \\
& 153 & $17,08^{\mathrm{b}}$ \\
\hline \multirow{4}{*}{ Serat kasar } & & \\
& & \\
& & \\
& &
\end{tabular}

Hasil uji statistik (Tabel 1) menunjukkan bahwa perbedaan asesi kacang panjang berpengaruh nyata terhadap kandungan serat kasar, lemak kasar, bahan kering dan bahan organik. Kandungan nutrient yang tertinggi yaitu nomor asesi 225 dengan kandungan bahan kering dan lemak kasar tertinggi $(15,69 \%$ dan 3,05\%). Serat kasar pada nomor asesi 225 menunjukkan hasil yang terendah yaitu $10,18 \%$. Nomor asesi 225 berasal dari Sukaharjo, JawaTengah. Valenzuela dan Smith (2002) menyatakan bahwa salah satu faktor yang mempengaruhi tinggi kandungan nutrient adalah unsur hara tanah.

\section{KESIMPULAN}

Berdasarkan hasil penelitian dapat disimpulkan bahwa nomor asesi kacang panjang yang memiliki produksi tinggi yaitu 141, 360, 225, 158 dan 153. Nomor asesi kacang panjang yang memiliki lemak kasar dan bahan kering tertinggi yaitu nomor 225 dengan serat kasar yang rendah.

\section{DAFTAR PUSTAKA}

AOAC. 2005. Official Method of Analysis of the Association of Official Analytical Chemistry. $18^{\text {th }}$ ed. Association of Official Analytical Chemists. Washington DC.

Anto, A. 2013. Teknolgi Budidaya Kacang Panjang. Available at https://kalteng.litbang.pertanian. go.id/ind/images/data/teknologi-kacangpanjang-2013.pdf. Diakses pada tanggal 11 November 2019.

Astuti, M. 1980. Rancangan Percobaan dan Analisa Statistik. Bagian Pemuliaan Ternak. Fakultas Peternakan UGM. Yogyakarta.

Haliza, W., E. Y. Purwani, dan R. Thahir. 2010. Pemanfaatan kacang-kacangan lokal mendukung diversifikasi pangan1. Pengembangan Inovasi Pertanian. $33: 238-245$.

Suryadi. 2003. Karakteristik dan deskripsi plasma nutfah kacang panjang. Balai Penelitian Tanaman Sayuran : Lembang. Buletin Plasma Nutfah. 9: 1-9.

Valenzuela, H. and J. Smith. 2002. Cowpea. Cooperative Extension Service, College of tropical Agric. And human resources. University of Hawaii. Manoa, Honolulu. Hawaii. P. 3. 